\title{
The art and learning patterns of knowing in nursing
}

\author{
AARTE E AAPRENDIZAGEM DOS PADRÕES DE CONHECIMENTO EM ENFERMAGEM \\ EL ARTE Y EL APRENDIZAJE DE LAS NORMAS DE CONOCIMIENTO EN ENFERMEIRA
}

\section{Cristina Lavareda Baixinho', Isabel Carvalho Beato Ferraz Pereira², Óscar Manuel Ramos Ferreira ${ }^{3}$, Helga Marilia da Silva Rafael ${ }^{4}$}

\begin{abstract}
Objectives: To identify the perception of the students about the use of art as a pedagogical strategy in learning the patterns of knowing in nursing; to identify the dimensions of each pattern valued in the analysis of pieces of art.

Method: Descriptive mixed study. Data collection used a questionnaire applied to 31 nursing students.

Results: In the analysis of the students' discourse, it was explicit that empirical knowledge includes scientific knowledge, tradition and nature of care. The aesthetic knowledge implies expressiveness, subjectivity and sensitivity. Self-knowledge, experience, reflective attitude and relationships with others are the subcategories of personal knowledge and the moral and ethics support ethical knowledge.

Conclusion: It is possible to learn patterns of knowledge through art, especially the aesthetic, ethical and personal. It is necessary to investigate further pedagogical strategies that contribute to the learning patterns of nursing knowledge.
\end{abstract}

\section{RESUMO}

Objetivos: Identificar a perceção dos estudantes acerca da utilização da arte como estratégia pedagógica na aprendizagem dos padrões de conhecimento em enfermagem; Identificar as dimensões de cada padrão valorizadas na análise das obras de arte.

Método: Estudo descritivo e misto. A coIheita de dados com recurso a um questionário, aplicado a 31 estudantes de enfermagem.

Resultados: $\mathrm{Na}$ análise do discurso dos estudantes está implícito que o conhecimento empírico inclui: conhecimento científico, tradição e natureza dos cuidados. O conhecimento estético implica: expressividade, subjetividade e sensibilidade. $O$ autoconhecimento, a experiência, a atitude reflexiva e a relação com os outros são as subcategorias do conhecimento pessoal e a moral e a ética suportam o conhecimento ético.

Conclusão: É possível aprender os padrões de conhecimento através da arte, sobretudo do estético, ético e pessoal. É necessário investigar mais as estratégias pedagógicas que contribuam para a aprendizagem dos padrões de conhecimento em enfermagem.

\section{DESCRITORES}

Enfermagem

Aprendizagem

Arte

\section{RESUMEN}

Objetivos: Identificar la percepción de los estudiantes sobre la utilización del arte como estrategia pedagógica en el aprendizaje de los patrones del conocimiento en enfermería;

Identificar las dimensiones de cada patrón valoradas en el análisis de las obras de arte. Método: Estudio descriptivo y mixto. La recogida de datos con recurso a una encuesta aplicada a treinta y un estudiantes de enfermería.

Resultados: En el análisis del discurso de los estudiantes está tácito que el conocimiento empírico incluye: conocimiento científico, tradición y naturaleza de los cuidados. El conocimiento estético implica: expresividad, subjetividad y sensibilidad. El autoconocimiento, la experiencia, la actitud reflexiva y la relación con los demás son las subcategorías del conocimiento personal, mientras que la moral y la ética soportan el conocimiento ético.

Conclusión: Es posible aprender los patrones del conocimiento a través del arte, sobretodo del estético, del ético y del personal. Es necesario investigar más las estrategias pedagógicas que contribuyan al aprendizaje de patrones de conocimiento de enfermería.

\section{DESCRIPTORES}

Enfermería

Aprendizaje

Arte

${ }^{1}$ Master in School Health; Lisboa School of Nursing; Unit of Development and Research in Nursing, Lisbon, Portugal. ${ }^{2}$ PhD in Nursing; Lisboa School of Nursing; Unit of Development and Research in Nursing, Lisbon, Portugal. ${ }^{3} \mathrm{PhD}$ in Education; Lisboa School of Nursing; Unit of Development and Research in Nursing, Lisbon, Portugal. ${ }^{4}$ Master in Medical-surgical Nursing; Lisboa School of Nursing; Unit of Development and Research in Nursing, Lisbon, Portugal. 


\section{INTRODUCTION}

Caring is a relational process that depends on the relationship between the caregiver and the person being cared for. Every human being is a being in relation ${ }^{(1)}$, from this meeting and this interaction affection arises, this is not restricted to the being affected, but also the response that is sent to whom it affects. It is because we allow ourselves to be affected by an emotional force that makes a request to who affects $\mathrm{us}^{(1)}$. This reciprocity leave the people involved in a situation of existential equality ${ }^{(2)}$.

If, indeed, the person can be defined as a being in relation, it is from this relation that affection is essentially linked to the personal dimension of human existence ${ }^{(1)}$.

On the other hand, the nursing work is between ethical action and technical work produced ${ }^{(1)}$, the nurse lives her/his openness to the world from the field of health and disease ${ }^{(1)}$, and the individual and collective processes of health/disease are extremely complex, requiring nursing, as a discipline and as an art, to become a mean that allows the transformation of knowledge and technical wisdom into a commodity put into service for others.

Under these assumptions, we assume that the provision of health care is not only from empirical knowledge, it is necessary that professionals make use of other types of knowledge. Carper has identified four fundamental patterns of knowing in nursing: empiric, esthetic, personal and ethics ${ }^{(3)}$.

Learning the different patterns of knowing is complex, depends not only on pedagogical strategies, but also implies self-social and moral development of nursing students. It is easier to learn from empirical knowledge, than the ethical, esthetic and especially person$\mathrm{al}^{(2)}$.

Based on the described above, and being professors of the Curriculum Unit of History and Epistemology of Nursing, in the Licentiate's Degree in Nursing, we have diverse pedagogical strategies in order to promote the process of teaching-learning and motivate students to discover the core elements of the discipline and the nursing profession.

Regarding patterns of knowing in nursing, we challenge its understanding through artistic expression, in order to awaken the sensitivity necessary to be a Nurse.

Therefore, the following objectives were established: To identify the perception of students about the use of art as a pedagogical strategy in learning the patterns of nursing knowledge; to identify the dimensions of each standard valued in the analysis of pieces of $\operatorname{art}^{(3)}$.

\section{METHODS}

An exploratory and descriptive study was conducted, with a predominantly qualitative approach. The sample was composed by 31students (S) of the first year of the Licentiate undergraduate course in Nursing. We used as instrument of data collection a questionnaire with closed and opened questions, which was sent online to students after they had participated in theoretical-practical classes. The class occurred according to the previously planned phases by professors (Box I).

Box 1 - Research protocol.

\begin{tabular}{ll}
\hline Phase I & $\begin{array}{l}\text { Preparation of the methodology of theoretical-practical } \\
\text { class. We included selection of piece of arts in group; }\end{array}$ \\
\hline Phase II & $\begin{array}{l}\text { Analysis of pieces of art in group and presentation of } \\
\text { results; }\end{array}$ \\
\hline Phase III & $\begin{array}{l}\text { Sending the instrument of data collection with the questions. } \\
\text { Response of students to the questionnaire; }\end{array}$ \\
\hline Phase IV & Data analysis ; \\
\hline Phase V & Discussion. \\
\hline
\end{tabular}

Firstly, we defined the objectives of each theoreticalpractical classes; selected pieces of art to be analyzed by the students (21 paintings, 1 drawing, 2 lithographs and 6 sculptures). The pieces of art represented nature of care or forms of care. The script for class orientation was made available 48 hours before the theoretical-practical classes, through the e-learning platform where objectives and methodology were explained, this platform contained a photograph of each of the selected pieces of art with respective subtitle.

This phase was prepared carefully; we asked three judges to validate the choice of pieces of art. This criterion was important to avoid bias in the analysis of future data, because researchers are key tools in the perspective of building data in order to know the reality ${ }^{(4)}$.

In phase II groups were organized (4-6 students per group), who analyzed the pieces of art from the stimulus placed: a) To identify a piece of art that represents caring; b) To describe the feelings that the piece of art has caused; c) To reflect on the inherent caring values present in the piece of art.

The students presented the results from work undertaken by the groups. In the end, the professor made an integrative synthesis of the main conclusions, showing Carper's patterns of knowing that had been intuitively discovered by student groups.

In phase III, fifteen days after the class, groups of students were given a questionnaire developed in Google Drive ${ }^{\circledast}$ with closed and opened questions. The first part allowed a characterization of the sample, evaluating the 
results, comparing the proposed objectives and collecting the perception of the students about the maintenance or not of the methodology. The second part was consisted of categories defined a priori (empirical knowledge, esthetic knowledge, personal knowledge and ethical knowledge) and sought to identify the attributes of each pattern of knowledge valued in the analysis of the students.

In phase IV, we proceeded to data analysis. Closed questions were submitted to descriptive statistics and content of the opened questions was subjected to content analysis, in order to critically understand the meaning of communications, their content and their meanings $s^{(5)}$. Qualitative research employs different philosophical concepts, research strategies, analysis and construction methods, data interpretation that allows us to understand the reality, always considering the complexity of factors that are involved ${ }^{(4)}$.

In this study we used the categorical thematic analysis proposed by $\operatorname{Vala}^{(6)}$, data were analyzed, the meaning contained therein was extracted and organized in subcategories from the previously defined categories, so that to be interpreted, always considering the ideas that are explicit and implicit ${ }^{(4)}$ in the text written by students.

\section{RESULTS}

The rate of participants was $48.3 \%$, obtained from 31 responses, out of 64 possible participants.

The average age of the sample was 19.8 , with $61.3 \%$ female and $38.7 \%$ male.

All participants considered that the pieces of art selected represented "care" and $84 \%$ considered that the pieces of art allowed the integration of knowledge in relation to the four patterns of knowing defined by Carp$\mathrm{er}^{(3,7)}$.

Through the analysis of Table I, we found that most students considered that the methodology used contributed greatly to the understanding of patterns of knowing in nursing. The methodology used promotes understanding of patterns of personal, ethical, esthetic and empirical knowledge. However, the latter pattern has the lowest expression in the responses of students
Content analysis of opened responses enabled the development of subcategories from the previously defined categories of sensing elements of learning valued by students $^{(6,7)}$.

For empirical knowledge category, students recognize that the methodology used "allowed us to realize that empirical knowledge can be understood by art" (S26). Three subcategories stood out: scientific knowledge, tradition and nature of nursing care.

Scientific knowledge is explicit in writing as "scientific knowledge, from research" (S1), "verifiable" (S7, S9, S21, S27, S31), "based on laws and theories" (S7), "which explains phenomena"(S25), is "objective" (S2, S10, S11, S12, S14), "based on the verification of phenomena and tries to explain and foresee them" (E13), which "can be scientifically verified through research" (S28), corresponds to the knowledge of the "nursing science" (S18).

The tradition appears in the definition of an own body of knowledge, based on what care have been throughout human evolution, described as "the importance of the evolution of knowledge over the centuries" (S19). The selected work represented "care situations over the centuries and the representation varied with the historical period, such as the piece of art" (S22), allowing the perception "how care and caregivers have evolved over time" (S20) related to the "experience" (S21).

In the subcategory nature of nursing care, the methodology "allowed us to observe different perspectives of care since antiquity" (S22), being clear "pieces of art whose pictures refer to the biomedical field by the presence of many medical equipment and other medical equipment's refer to a more humane attitude from professionals" (S25).

In the Esthetic knowledge category, the subcategories expressiveness, subjectivity and sensitivity emerge. This pattern of knowing was also understood by the students from the class as something that "allowed us to see in practice what was the esthetic knowledge and how this could be understood from the art perspective" (S3), it brings us to the history and to think in the perspective of Florence Nightingale to define nursing as the most beautiful of the arts" (S14).

The expression derives from the "interaction nurse/ patient" (S22). This is an artistic knowledge, depending on the "creativity" (S24) of the nurse, with a "symbolic

Table 1 - Contribution of theoretical- practical classes for understanding the patterns of knowing in nursing

\begin{tabular}{|c|c|c|c|c|c|c|}
\hline $\begin{array}{l}\text { Patterns of knowing } \\
\text { in Nursing }\end{array}$ & $\begin{array}{c}1 . \text { No } \\
\text { contribution }\end{array}$ & $\begin{array}{c}\text { 2. Little } \\
\text { contribution }\end{array}$ & $\begin{array}{l}\text { 3. Sufficiently } \\
\text { contribution }\end{array}$ & $\begin{array}{c}\text { 4. Good } \\
\text { contribution }\end{array}$ & $\begin{array}{l}\text { 5. Integral } \\
\text { contribution }\end{array}$ & total \\
\hline Empirical & $3.2 \%$ & $29.1 \%$ & $35.5 \%$ & $25.8 \%$ & $6.4 \%$ & $100 \%$ \\
\hline Esthetic & $0 \%$ & $6.4 \%$ & $3.2 \%$ & $54.9 \%$ & $35.5 \%$ & $100 \%$ \\
\hline Personal & $0 \%$ & $6.4 \%$ & $12.8 \%$ & $48.5 \%$ & $32.3 \%$ & $100 \%$ \\
\hline Ethical & $0 \%$ & $3.2 \%$ & $6.4 \%$ & $74.3 \%$ & $16.1 \%$ & $100 \%$ \\
\hline
\end{tabular}


dimension and refers to the creation and assignment of meaning (...) expressed through actions and attitudes" (S25), visible in "actions/interactions that we can move to the nurse-client relation" (S26), is "experiential" (S7, S8, S26), implies "involvement" (S30) and "is artistic because it involves creating something to express" (S19).

Subjectivity is manifested by the "variety of perceptions from individual to individual" (S8), depends on the "individual interaction" (S10) and involves "emotions and feelings" (S31). "We observed this pattern in the piece of art that we chose, as it was possible to observe references to the importance of caring and the sensitivity of the meaning of a moment" (S23).

This type of knowledge comprises the sensitivity, because despite being a "non-formal" (S9) knowledge, "is sensitive to the meaning of a particular moment" (S1), "'” "addresses the sensitivity of the other" (S2) and the own "sensitivity of the meaning of a moment" (S23), because it involves "seeing the other in its integrity" (S26), contemplating "fragility, sensitivity, compassion" (S30).

Described by this knowledge, "known as the art of nursing" (S31), enables the "practice of nursing as well as the extraction of meaning in meetings with patients" (S4), "establishing as one of the meanings of the art of nursing" (S29).

The added value of the methodology to learn what is esthetic knowledge have allowed to "understand the sensitivity of the meaning of a moment through the various representations of care and recognize nursing as art" (S29), even though a knowledge has a "very symbolic dimension and refers to the creation of a unique and subjective meaning which requires a certain sensitivity that can be expressed through actions and attitudes" (S22).

In the personal knowledge category, the subcategories are self-knowledge, experience, reflective attitude and relationship with others.

Students reinforces that this type of knowledge is "dependent on the self-knowledge (S2, S4, S7, S18) "and from the subjectivity inherent in every single individual" (S4), "the way I see myself and others" (S2) and how professional "sees the situation, which depends on the personality of each one" (S14). It is "important to know ourselves to know how to deal with others" (S17).

Incorporates the experience (S2, S6, S10, S11, S12, S15), because "the more experience she has, more able she will be" (S9). Experiences give us "a unique personal understanding" (S31), which contributes to the "experience, maturity and freedom" (S7) and enables the development of "intuition" (S17).

Depends on "relationships with others" (S2), "the recognition of each opinion within each group" (S4) and how "I see others" (S21, S29).

It is reflective. It is crucial that there is "intro and ret- rospection" (S10), as this knowledge is "generated by the person depending on her/his life experiences, which makes the self- reflection" (S11), "manifesting itself in practice" (S16).

In the category ethical knowledge, moral and ethics emerges as the subcategories.

Regarding moral, participants value the "moral code" (S1, $\mathrm{S} 2$ ) and the "moral component of nursing" (S8, S21), arguing that nurses should "have a right conduct, wisdom in differing what is good from what is bad and respect for another human being" (S5). This conduct includes "all deliberated and voluntary actions subjected to judgment" (S21).

Regarding ethics, students consider that "almost all pictures transpired ethical principles about the care" (S2). From an ethical view, reinforced the need to "respect human life" (S1, S13), "evaluate what is good and valuable to humans and respect" (S3). This knowledge "understands the values, principles and ethical codes from which we can assess what is desirable and undesirable in the face of a situation" (S8), defines "a set of moral values inherent to society" (S15) and allows the realization of "the multiplicity of values" (S23).

Thus, they consider that in clinical practice there is a need to "assess what is desirable for humans" (S18). The complexity of ethical dilemmas, nurses have "patterns and ethics code of the profession (S21), which valued the importance of "informed consent" (S27, S30) and the "respect for life" (S4, S8, S30).

\section{Figure 1 - Lithograph by Paula Rego "Nursing"}

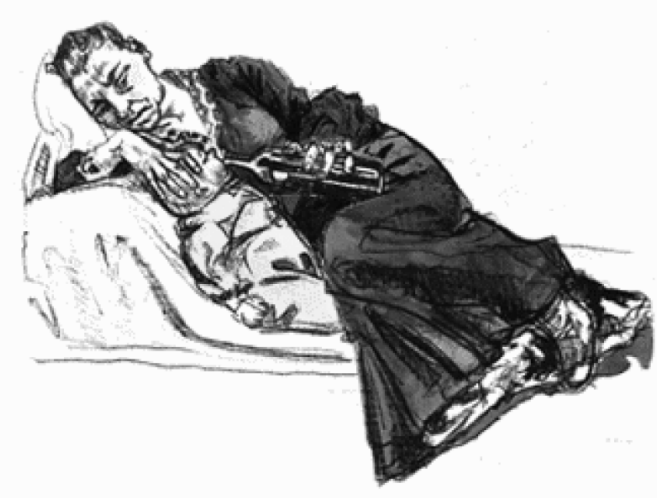

Paula Rego Nursing - lithograph, edition of $35-59.3 \times 47$

Source: http://www.casadashistoriaspaularego.com/en/collection/ engraving.aspx

Some pieces of art "such as Paula Rego were controversial and that enabled working individual moral and ethical context, and evaluate the pieces of art from the point of view of ethics in nursing, as well as understanding how 
this ethical knowledge varies with the temporal, historical and social contexts" (S12), the class allowed students to realize the "relationship between the ethical patterns and the provision of care" (S23), because "almost all the pictures were transpired professionalism in the provision of health care" (S2).

The methodology "allowed the development of the ability to assess what is good, beneficial and desirable" (S7).

\section{DISCUSSION}

When analyzing the nursing literature, Carper identified four patterns of knowing in nursing, which are currently valued and used in research and nursing practice ${ }^{(3)}$.

Although there are more recent studies that cite other types of knowledge, including intuitive knowledge ${ }^{(8-10)}$ we used Carper's classification to be accepted and widely discussed in the scientific community.

The concern with the definition of a specific field of knowledge in Nursing did not start with this study, along with the historical process of the profession, there has been a concern of validating this knowledge. Finding a variety of ways in which this has been built, expressed in models and theory produced by nurses and recognized by the scientific community ${ }^{(7,10,11)}$. It is generally agreed that nursing, as a discipline is to define its frontiers and therefore needs to define its own ways of knowing, producing and validating its knowledge $\mathrm{e}^{(12)}$.

The theories developed in the discipline and the knowledge it produces are essential for Nursing, they do not only allow delimitation of a field of expertise, but also promote an evidence-based practice ${ }^{(8,9)}$, allowing nurses from clinical practice to solve problems that arise in their daily basis ${ }^{(10)}$. However, a clinical practice based only on a single type of knowledge is not possible because nurses deal with human beings ${ }^{(2)}$ and due to the nature of nursing care depend on another type of knowledge to respond competently to the care needs, increasingly more complex from users of health care in order to promote a safe clinical practice.

In the analysis of students' discourse empirical knowledge emerges, apart from scientific knowledge validated by research, it is delimitated by tradition and nature of nursing care $^{(7)}$.

This pattern of knowledge is objective and generally amenable to quantification, discursively formulated and verifiable ${ }^{(3)}$. When confirmed by the use of repeated testing over time, allows scientific generalizations, laws and theories that explain principles and foresee phenome$\mathrm{na}^{(10)}$. It is factual and verifiable ${ }^{(7)}$, as it appears in the responses.

The sample refers to the importance of empirical knowledge to practice of care, since the purpose of the research is to improve nursing care practice ${ }^{(7,10)}$ and understand that the nature of knowledge and the way it is designed is conditioned by history, by the dominant values and resources ${ }^{(12)}$.

The science of nursing relates to the construction of knowledge on human responses ${ }^{(7,10,11)}$, responses that have varied over time ${ }^{(13)}$. The objective of the science of nursing is to represent the nature of nursing to understand, explain and use it for the benefit of humanity ${ }^{(10)}$. Therefore, the knowledge produced has to predict the nature of care and the different ways of caring ${ }^{(7)}$.

The esthetic knowledge, also known as the art of nursing, is expressed through the actions, behaviors, attitudes, practices and interactions with people ${ }^{(3)}$, is expressive, subjective and becomes visible in the act of caring ${ }^{(7,12)}$.

Florence Nightingale stated that nursing was an $\operatorname{art}^{(14)}$, an art that requires as exclusive as devotion, such a rigorous preparation, as the work of any painter or sculptor, he considered one of the finest $\operatorname{arts}^{(14)}$.

Art is related to professional practice, in other words, the art is expressed in the interaction process between nurse and client, awakening the client's ability to face challenges $^{(7,12)}$. Thus as art that nursing is, it not limited to imitate the real, intervenes on it, transforms it ${ }^{(15)}$.

The art of nursing cannot be reduced to simple techniques applications, in fact this was one of the factors that led to the devaluation of this form of knowledge ${ }^{(12)}$. We assume to care for the other ${ }^{(15)}$ and is expressed in the interaction process between nurse and client, awakening the client's ability to face challenges ${ }^{(12)}$.

Students consider that this type of knowledge is subjective, associated with expressiveness and sensitivity of the nurse, manifesting itself in the relation to the person $^{(7)}$. Implicit here is the idea that aesthetic knowledge refers to how the care is shown to the perception and experience of the other ${ }^{(16)}$. Are core elements of aesthetic: intuition, interpretation, understanding and value ${ }^{(3,12)}$.

Students describe that this type of knowledge comprises the sensitivity, because despite being a non-formal knowledge, has to meet the expectations of the other and the significance of the moment ${ }^{(7)}$. To the expressiveness of this pattern, which "is artistic" (S24), contributes to creativity, this leads to the development of the caregiver and the cared person" $7,12,15)$, implies "seeing the other in its integrality" (S26), which is a human capacity that is lacking on science and in general life ${ }^{(17)}$.

The esthetic knowledge can be related with the know how, which allows working with unquantifiable phenomena and what cannot be explained by laws and theories ${ }^{(12)}$.

Described by, we cannot get the notion that the aesthetic is confined to art and to the beautiful, since the aesthetic experience allow us to live the objective and the 
subjective, in order to know differences you need creativity, sensitivity, intuition, knowledge, among other indispensable to own reflection ${ }^{(17)}$. We highlight that not every action has an aesthetic quality, because for this to occur, there must be a unit of ends and means ${ }^{(12)}$.

Personal knowledge is the most difficult to master and teach ${ }^{(7,12)}$. It is the knowledge of oneself and is the basis of the relationship that is established with others ${ }^{(3)}$, it is subjective, concrete and existential ${ }^{(12)}$ and for students is associated with self-knowledge, experience, reflective attitude and the relationship with each other ${ }^{(7)}$. Includes intuitive and humanistic knowledge proposed by other authors ${ }^{(16)}$.

In the literature three aspects of personal knowledge are identified: knowing yourself, knowing what (explicit knowledge) and knowing how (implicit or practical knowledge) $)^{(7,12)}$.

As referred students, this knowledge is generated by the person, being crucial that there is "intro and retrospection" (S10) $)^{(7)}$.

Personal knowledge refers to the way nurses view themselves and others ${ }^{(3,10)}$, related to the understanding of the individual self, concrete ${ }^{(12)}$. The therapeutic use of self implies an approximation of the client as subject and the acceptance of their freedom ${ }^{(16)}$.

Reflecting about the knowledge we use in care practice provides understanding the complexity of the relationship between knowing and doing in nursing ${ }^{(17)}$.

This form of relationship between doing and knowing, clearly links this pattern with empirical knowledge, whenever the professional express their knowledge through language. However, self-claiming leads to personal knowledge $^{(12)}$.

Students consider that the experience allows a better personal knowledge, "personal knowledge is subjective, reflected in practice and is shaped by the experience of the individual himself" (S13). This data can be explained by the average age and the uncertainty associated with clinical practice, which may lack experience, but about which they know to be extremely complex ${ }^{(7)}$.

The maturity and freedom are components of personal knowledge, which may include spiritual and metaphysical forms ${ }^{(10)}$, because "the more experience she has more able she will be" (S9) ${ }^{(7)}$. Some consider the passage of nonexpert to expert of a relation with oneself, with others and a relationship with himself through relationship with others is what allow us to establish a relationship of distancing-regulation with the type of knowledge ${ }^{(12)}$.

We believe that this variable should be explored in future studies to identify the pedagogical experiences with greater potential in developing this type of knowledge in students $^{(7)}$.
In the category ethical knowledge, moral and ethical emerged as subcategories. Ethics refers to the moral code of nursing and is based on the obligation to serve and respect human life $\mathrm{f}^{(3,10)}$. The ethical knowledge is developed as the moral dilemmas arise in situations of ambiguity and uncertainty, and when the consequences are hard to pre$\operatorname{dict}^{(10)}$. The ethical knowledge determines what is good, valuable and desirable ${ }^{(3,10)}$.

In their daily practice, nurses need to establish objectives and conduct interventions that are appropriate to clients, implying assessments, evaluations and decide on what is appropriate and suitable for every situation ${ }^{(12)}$.

For some authors, ethics and esthetics are two sides of the same coin ${ }^{(16,17)}$, whose combination determines the type of care, including various ways to construct the process $^{(17)}$, allowing the construction of responsible actions, with the use of all knowledge, allowing an individualized and evidence-based care with respect for dignity and human life ${ }^{(7)}$.

The increasing technicality of health care and the complexity of disease processes make health professionals facing ethical choices of nature that cannot be made solely from the code of ethics, which makes the development of ethical knowledge imperative ${ }^{(12)}$.

In the students' opinion, the methodology used had a greater contribution to the understanding of the patterns of esthetic, personal and ethical knowledge than for understanding the patterns of empirical knowledge. There was no justification for this fact in the literature. The results may be due to the very nature of empirical knowledge, more objective, measurable, observable and verifiable, and therefore, less associated with the pedagogical strategy used(7).

\section{CONCLUSION}

The provision of care for a concrete client, in a given context is demanding, complex, and its exercise requires the expertise of a number of skills and knowledge, which must be acquired in undergraduate training courses, which need to privilege the specific ways to professional knowledge for a person who wants to be qualified, thus planning the teaching-learning process is essential to determine how to acquire the desired and necessary knowledge ${ }^{(12)}$.

For the presentation and discussion of results, we analyzed separately the four patterns of knowledge, but these are interconnected and influence each other in the practice of $\operatorname{care}^{(3)}$, none is sufficient alone and neither are mutually exclusive. Rather, care requires knowledge of the Nursing science, but the creative imagination is also important in scientific discovery and the development of skills to imagine the potential consequences of moral choices $^{(16)}$. 
The strategy we used was different, having been positively evaluated by participants. We conclude that art is a pedagogical tool that allows the development of skills while promoting confidence and the expression of emotions ${ }^{(7)}$.

From the discourse analysis of students subcategories for different patterns emerged: empirical (scientific knowledge, tradition and nature of care), esthetic (expressivity, sensitivity and subjectivity), personal (self-knowledge, experience, reflective attitude and relationship with others) and ethical (moral and ethics) ${ }^{(7)}$.

As we reflect on the learning process, we observed that teaching and learning also involves empirical, ethical, esthetic and personal knowledge expressed in the pedagogical relationship and in the singular encounter be-

\section{REFERENCES}

1. Renaud I. Ser pessoa: contributo para uma visão global da pessoa. Brotéria. 2007; 164:111-130.

2. Watson J. Nursing: the philosophy and science of caring. Boston: Little Brown; 2002.

3. Carper B. Fundamental patterns of knowing in Nursing. Advances in Nursing Science. 1978; 1(1):13-24.

4. Creswell W. Métodos qualitativos. In: Creswell JW, organizadores. Projeto de pesquisa. Porto Alegre: Artmed; 2010.

5. Chizzotti A. Pesquisa em ciências humanas e sociais. São Paulo: Cortez; 2002.

6. Vala JA. Análise de conteúdo. In: Silva, AS, Pinto JM. Metodologia das ciências sociais. Porto: Editora Afrontamento; 1999.

7. Baixinho C, Pereira I, Ferreira O, Rafael H. A arte como estratégia pedagógica: para a aprendizagem dos padrões de conhecimento em enfermagem de Carper. In Costa C, Reis L, Souza $\mathrm{F}$, Luengo R, editores. Livro de Atas do 3 Congresso Ibero-Americano de Investigação Qualitativa; 2014 Jul 14-16; Badajóz, Espanha. vol. II,. P. 32-37.

8. Kenny C. Nursing intuition: can it be researched? British Journal of Nursing. 1994; 3(22):1191-119.

9. English I. Intuition as a function of the expert nurse: a critique of Benner's novice to expert model. Journal of Advanced Nursing. 1993; 18(3):387-393. tween those who teach and those who learn, where both actors are involved in a relationship of discovery not only knowledge, but also in existence ${ }^{(7)}$.

We believe that this methodology can be extended to the self-study of students, providing museums visits, exhibitions, among others, as one student stated "I never thought I could learn nursing from the art, but here I've seen some movies about people who have influenced the care, I have analyzed pieces of art... and I think I have another sensitivity when I go to the hospital" $(\mathrm{S} 31)^{(7)}$.

This study has limitations because of the specific context, with its own influences. The results cannot be generalized to other contexts and prevent the operationalization of theoretical relationships.

10. McEwen M, Wills E. Theoretical basis for Nursing. Philadelphia: Lippincott Willians \& Wilkins; 2011.

11. Meleis A. Theoretical nursing: development and progress. Philadelphia: Lippincott Williams \& Wilkins; 2012.

12. Cestari M. Padrões de conhecimento da enfermagem e suas implicações no ensino. Rev Gaúcha Enfermagem. 2003;24(1):34-42.

13. Coliére M. Promover a vida. Lisboa: Sindicato dos Enfermeiros Portugueses; 1989.

14. Nightingale F. Notes on nursing. What it is, and what it is not. New-York: D. Appleton and Company; 1860.

15. Rodrigues A. A dimensão estética do cuidar em Enfermagem. Revista Referência. 2002; supl.

16. Madureira V. Os saberes da enfermagem. Rev Bras Enferm. 2004; 57(3):357-360.

17. Hammerschmidt K, Borghi A, Lenardi M. Ética e estética na promoção do cuidado gerontológico em enfermagem. Texto Contexto Enfermagem. 2006; 15(Esp):114-124. 